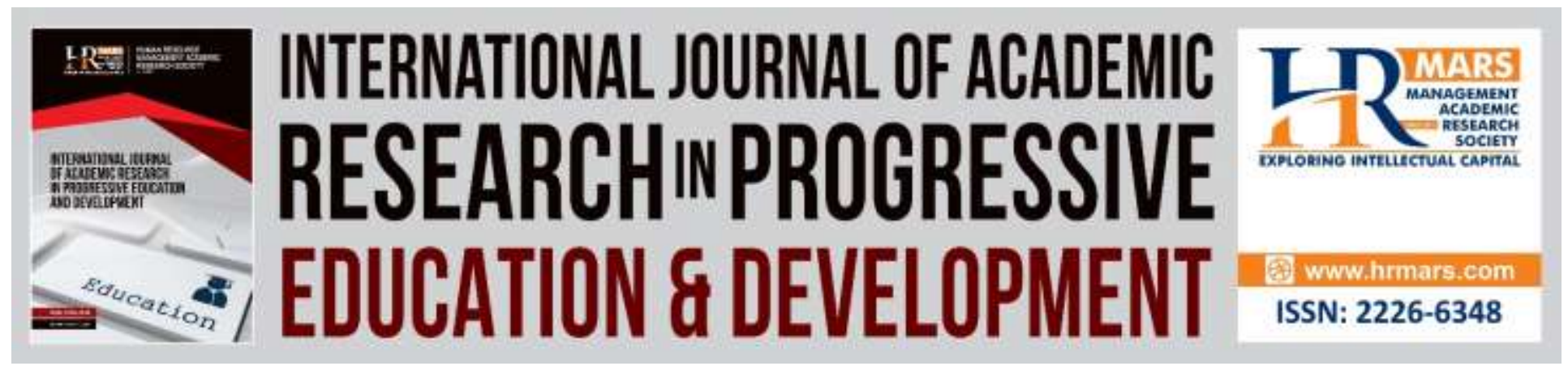

\title{
Reinforcement of Students' Higher Order Thinking Skills through Project Based Learning with Scaffolding
}

Nor Sa'adah Jamaluddin, Suhaida Abd Kadir, Arnida Abdullah, Siti Noormi Alias

To Link this Article: http://dx.doi.org/10.6007/IJARPED/v8-i4/6496

DOI:10.6007/IJARPED/v8-i4/6496

Received: 11 August 2019, Revised: 20 September 2019, Accepted: 01 October 2019

Published Online: 20 October, 2019

In-Text Citation: (Kadir, Abdullah, \& Alias, 2019)

To Cite this Article: Kadir, N. S. J. S. A., Abdullah, A., \& Alias, S. N. (2019). Reinforcement of Students' Higher Order Thinking Skills through Project Based Learning with Scaffolding. International Journal of Academic Research in Progressive Education and Development, 8(4), 230-244.

Copyright: (C) 2019 The Author(s)

Published by Human Resource Management Academic Research Society (www.hrmars.com)

This article is published under the Creative Commons Attribution (CC BY 4.0) license. Anyone may reproduce, distribute, translate and create derivative works of this article (for both commercial and non-commercial purposes), subject to full attribution to the original publication and authors. The full terms of this license may be seen at: http://creativecommons.org/licences/by/4.0/legalcode

Vol. 8(4) 2019, Pg. 230- 244

http://hrmars.com/index.php/pages/detail/IJARPED

JOURNAL HOMEPAGE

Full Terms \& Conditions of access and use can be found at

http://hrmars.com/index.php/pages/detail/publication-ethics 


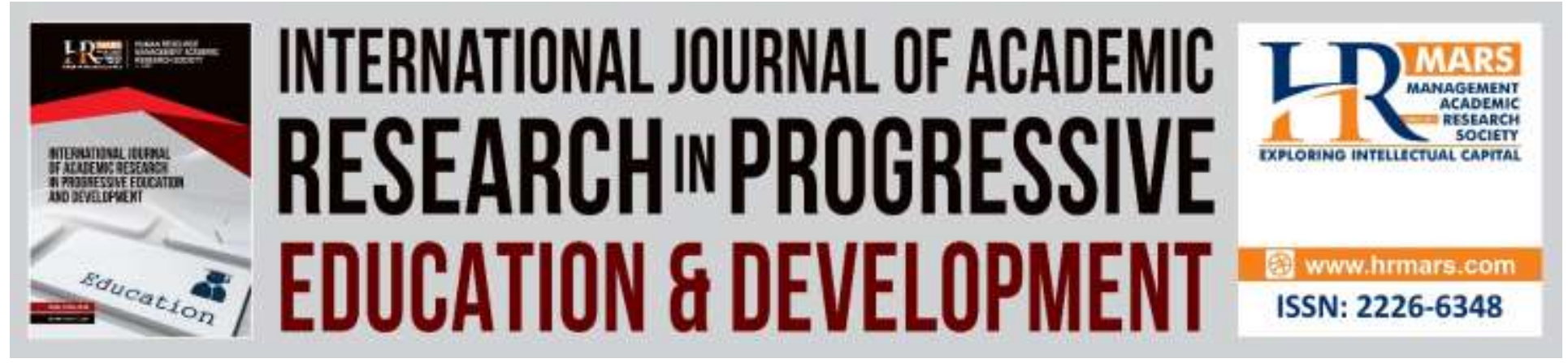

\title{
Reinforcement of Students' Higher Order Thinking Skills through Project Based Learning with Scaffolding
}

\author{
Nor Sa'adah Jamaluddin, Suhaida Abd Kadir, Arnida Abdullah, \\ Siti Noormi Alias
}

Faculty of Educational Studies, University Putra Malaysia

\begin{abstract}
Higher Order Thinking Skills is one of the six students' aspirations that focus on the education 'Blueprint' or Malaysia Educational Development Plan (MEDP) 2013-2025. Producing students that have good and successful mastery level of HOTS could prepare the students in competing at global education scene aside from creating students with high marketability value. A good and successful mastery of HOTS is related to Teaching and Learning strategy that is utilized by teachers in schools. Choosing the correct and suitable Teaching and Learning strategy could transform the students' mind to think creatively, critically, and innovatively in completing a task or solving a problem. Application of Project Based Learning (PBL) is one of the common Teaching and Learning strategy that is emphasized in schools. A research is carried out towards Form 4 Accounting students in studying the effect of PBL towards mastery of HOTS precisely in topic 'cash budget' with the involvement of scaffolding element. The research uses quasi-experimental method that includes one experimental group participating in pre-test and post-test. Computerized statistical software "IBM SPSS Statistics" version 22 is utilized for the purpose of data analysis. Results from paired t-test show that there is a significant difference between the mean of the students' mastery level of HOTS in pre-test and post-test that involves PBL with scaffolding. Therefore, the involvement of scaffolding element in PBL contributes towards increase in students' mastery of HOTS and proofed that PBL is suitable to be implemented in Teaching and Learning session in schools.
\end{abstract}

Key words: Project Based Learning, Scaffolding, Higher Order Thinking Skills, Education Blueprint

\section{Introduction}

The national education transformation is composed through the creation of education 'Blueprint' or Malaysia Educational Development Plan (MEDP) 2013-2025 that aims towards a quality education system at par with national level (Ministry of Education Malaysia, 2017). Providing a 
quality education should be the main focus in ensuring Malaysia's overall development sustainability could be achieved as quality education is the core of national development (Yusof, 2017). In relation to producing a quality education, MEDP 2013-2025 has highlighted the requirement for the students to master the 21st century skills in order to ensure that the students have high marketability value as well as able to compete within the global market (Arshad \& Yasin, 2015). The 21st century skills that are emphasized in MEDP 2013-2025 include learning and innovation skill, information skill, media and technology, and life and career skills (Curriculum Development Department, 2016). Elements included in 21st century skills that are given the main focus within the six students' aspirations through MEDP 2013-2025 is Higher Order Thinking Skills (Curriculum Development Department, 2016).

Higher Order Thinking Skills (HOTS) is a skill that is deemed difficult to be mastered by the students due to lack of support and exercise in using the skills given by the teachers and even among the students (Hassan, 2017; Wijnen et al., 2017. Kikas \& Jogi, 2016; Bathuma \& Kalaimakal, 2014). Nevertheless, the teachers' successfulness in applying various methods and techniques in Teaching and Learning session had elevated the difficulty in mastering HOTS (Kizkapan \& Bektas, 2017). Hence, various techniques and methods in carrying out Teaching and Learning session must be mastered and practiced by teachers in schools in order to ensure the transformation of the students' mind align with the government's desire in education transformation through MEDP 2013-2025.

In order to improve the students' learning performance, integration between skills, knowledge and value became the main focus in executing Teaching and Learning session (Curriculum Development Department, 2016). Unity between skills, knowledge and values element can be easily achieved by selecting active teaching and learning strategy or student-based strategy that has the purpose of preparing the students with the ability to merge new information with prior knowledge in creating new knowledge through social interaction between teacher, students, and the environment (Ismail \& Othman, 2017). Project based learning, independent learning, and problem solving based learning and inquiry are some of the method and technique that are fit to be applied in Teaching and Learning ( $T n L)$ session in school particularly for accounting instructions (Curriculum Development Department, 2016).In regards to this research, project based learning is the main focus in evaluating accounting students' mastery of HOTS by applying constructivism theory as the banch mark (Kizkapan \& Bektas, 2017) with the involvement of scaffolding element during Teaching and Learning $(\mathrm{TnL})$ session in schools.

\section{Higher Order Thinking Skills}

In line with development of knowledge and technology era, higher order thinking skills (HOTS) is deemed as a skill that must be mastered by every student to ensure that they are ready to meet the global market requirement (Saregar et al., 2016). Students that are actively developing understanding through the process of interconnecting between prior knowledge and new 
Vol. 8, No. 4, 2019, E-ISSN: 2226-6348 @ 2019 HRMARS

knowledge best describe the concept of HOTS (Lin \& Lin, 2016). Lin and Lin's view (2016) is reinforced by Heong et al., (2011) view in which they stated that HOTS concept refers to individual's ability to think broadly and deeply in order to acquire new knowledge.

Next, referring to Bloom's Taxonomy: remembering and understanding skills are categorized as Lower Order Thinking Skills (LOTS) while applying, analyzing, evaluating and creating are classified as HOTS (Anderson \& Krathwohl, 2001). Williams (2003) stated that HOTS is not solely about knowing a fact but also understanding, analyzing and evaluating information to solve arising problem. The ability to understand, analyze, evaluate and finding new solutions towards a problem proofed the students' capability to connect the acquired knowledge which eventually prepare the students with 21st century skills in facing real life situation (Chen, 2017). Implementation of HOTS in Teaching and Learning is highly related to the role played by teachers during the execution of the session as well as selection of Teaching and Learning technique and method. Involvement of questioning, problem solving, decision making, generating idea, organizing thoughts and creativity are some of the basic elements that should be applied in order to ensure the Teaching and Learning technique support the reinforcement of students' HOTS (Conklin, 2012).

The process of reinforcing HOTS is slightly disturbed due to the behavior of some teachers that teach with the purpose of spoon-feeding the students (Onosko, 1991). The reason the teachers behave as such is to ensure the students pass the examination aside from making sure the syllabus is completed within the prescribed time-frame thus neglecting the students' mind transformation (Onosko, 1991). Therefore, this research is carried out in order to gain further information regarding the usage of project based learning technique that is proven by previous researchers could strengthen the students' HOTS, (Conklin, 2012). For this research, evaluation of accounting students' mastery of HOTS is measured based on HOTS concept that is emphasized by MOE in 21st century skills, referring to Revised Bloom Taxonomy 2001 (Anderson \& Krathwohl, 2001) that classifies remembering and understanding skill as LOTS and applying, analyzing, evaluating, and creating as HOTS as shown in Figure 1.

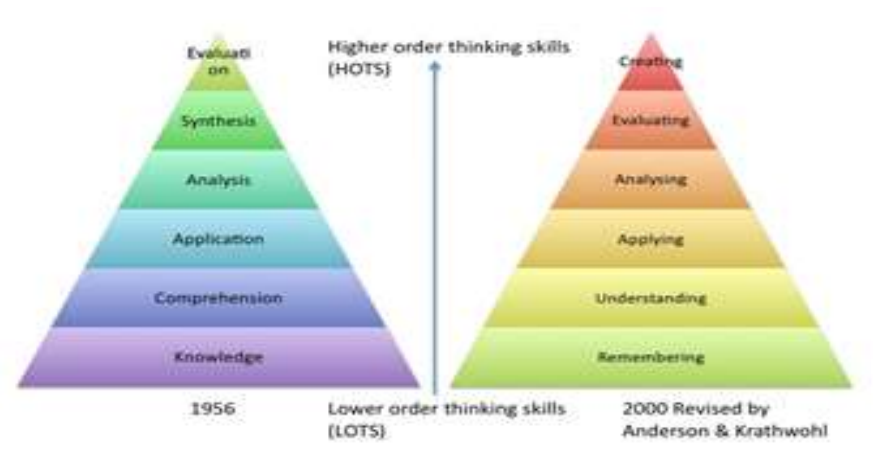

Figure 1: Bloom Taxonomy Hierarchy, Adaptation from Anderson \& Krathwohl (2001) 
Vol. 8, No. 4, 2019, E-ISSN: 2226-6348 @ 2019 HRMARS

\section{Project Based Learning}

Project based learning (PBL) strategy is one of the constructivist's teaching and learning strategy (Kizkapan \& Bektas, 2017; Frank \& Barzilai, 2004). It is also an alternative that supports education transformation (Curriculum Development Department, 2016; Guthrie; 2008) and is suitable to be carried out in preparing the students with 21st century skills (See et al., 2015). MEDP (2013-2025) even recommend the teachers to intensify Teaching and Learning session by making sure the six pillars in Secondary School Curriculum Standard framework which are Communication, Spiritual, Attitude and Value, Humanity, Self-Appearance, Physical and Aesthetic Development, and Science and Technology are highlighted because these six pillars are the main domain that support each other and are integrated with critical, creative and innovative thinking.

PBL in this research context refers to a model that is written particularly to improve classroom activity that is teacher-centred into constructivist-oriented teaching through active studentcentred classroom activity (Othman \& Osman, 2014) which indirectly integrates real life issue and practice (Nordin, 2013; Barak \& Shachar, 2008). PBL is viewed by past researchers as the right and the best platform in nurturing students' higher level cognitive skills aside from inducing meaningful learning (Kizkapan \& Bektas, 2017) as well as providing students with various potential that is integrated and inclusive (Curriculum Development Department, 2016). However, the need to create detailed planning slightly interferes with the execution of PBL (Robinson, 2013).

Based on the model that is written specifically for this research purpose, teachers' involvement as facilitator is accentuated as the teachers are the ones that assist the students in their mind transformation process towards higher level (McLeod, 2007). Wood et al., (1976) stated that the students' mind transformation process that involves the teachers' interference is known as scaffolding and it refers to proximal zone based on Vygotsky's view (McLeod, 2007; Vygotsky, 1978).

\section{Scaffolding}

Providing various supports (Bowles et al., 2017) in ensuring knowledge is gained among the students through constructivist learning environment is the basic concept of scaffolding that is related to social theory originated by Vygotsky (1978). The formation of structured framework by the teachers to supervise the students' development in attaining knowledge proofed the importance of supporting element in Teaching and Learning session. Hence, this explains the contribution of project based learning with scaffolding strategy towards students' successful cognitive development. For this research, 11 levels of learning in Erdem model (2002) that is adapted from Moursund model (1999) is made as reference as portrayed in Table 1. 
INTERNATIONAL JOURNAL OF ACADEMIC RESEARCH IN PROGRESSIVE EDUCATION AND

DEVELOPMENT

Vol. 8, No. 4, 2019, E-ISSN: 2226-6348 ๑ 2019 HRMARS

Table 1. Project Based Learning Levels Level Activity

1 Identifying teaching and learning objective

2 Identifying and determining the problems that must be solved by the student

3 Identifying the characteristics of report and presentation format

4 Identifying evaluation criteria

5 Create groups

6 Identifying guided questions as suggested by the teacher

7 Planning information gathering process

8 Planning and preparing work schedule

9 Identifying checklist

1C Gather, sort and write reports

11 Present findings and provide conclusion

Source: Moursund (1999) and Erdem (2002)

\section{Problem Statement}

Emphasis on traditional teaching and learning strategy that forbid the students' active participation cause the inhibition of students' mind development. Research by Nooriza and Effandi (2015) showed that teacher-centred learning hinders the students' mind transformation which eventually affects their academic performance. As for application of student-centred learning, it is proven that it could support the students' mind development in terms of cognitive, meta-cognitive and affective aspects (Wilkin, 2017).

Education scenario that is exam oriented cause failure in grasping and utilizing various techniques in Teaching and Learning among teachers thus affect the students' development of generic skills. Excitement in achieving good exam results cause learning activity did not occur holistically. Furthermore, the teachers have limited time to apply diverse techniques during Teaching and Learning session (See et al., 2017). Nevertheless if various techniques are applied during Teaching and Learning session, the students would not only succeed in their academics but the students would also be equipped with 21st century skills such as communication skill, problem solving skill and also higher order thinking skill (Yusof, 2017; Abosalem, 2016). Therefore, this research is conducted in order to evaluate Form 4 accounting students' performance through application of $\mathrm{PBL}$ strategy with the involvement of scaffolding element. 
INTERNATIONAL JOURNAL OF ACADEMIC RESEARCH IN PROGRESSIVE EDUCATION AND DEVELOPMENT

Vol. 8, No. 4, 2019, E-ISSN: 2226-6348 @ 2019 HRMARS

\section{Research Objectives}

The purpose of this research is to detect whether application of PBL strategy affect the Form 4 students' mastery of HOTS particularly in accounting instructions. The research hypotheses are:

H01: There is no significant difference in mastery of applying skill through PBL during pre-test and post-test.

H02: There is no significant difference in mastery of analysing skill through PBL during pre-test and post-test.

H03: There is no significant in mastery of evaluating skill through PBL during pre-test and posttest.

H04: There is no significant difference in mastery of creating skill through PBL during pre-test and post-test.

\section{Methodology}

This research is carried out in Private Secondary Schools in Selangor within 5 weeks by implementing quasi-experiment method through one group pre-test and post-test research design. One group pre-test and post-test research design is presented in Table 2.

Table 2. One Group Pre-Test and Post-Test Research Design

\begin{tabular}{cccc}
\hline Group & Pre-Test & Treatment & Post-test \\
\hline Group & $\mathrm{T}_{1}$ (Pre-test performance) & $\mathrm{X}$ (Treatment Group) & $\mathrm{T}_{2}$ (Post-test Performance) \\
\hline & Source: One group Pre-test and Post-test Research Design (Sidek, 2002)
\end{tabular}

One group pre-test and post-test research design includes one experimental group in order to detect the effect of independent variable that involves a research sample of 40 Form 4 Accounting students that took accounting instructions. The research sample is given two similar tests during different time in which pre-test is carried out after executing PBL without scaffolding while post-test is carried out after executing PBL with scaffolding. Instruments that are used in this research are one set of pre-test questions and one set of post-test questions. Pre-test and post-test are performed to measure the students' mastery level of HOTS particularly applying, analyzing, evaluating, and creating skills aspects for "Cash Budget" topic.

Data gathering process in this research involves four stages of execution namely: (1) 5 days before the treatment process, all respondents from both groups will receive explanation regarding the project execution and pre-test is given, (2) All respondents are given 4 weeks (treatment period) to ensure the planned activities are understood clearly to ease the implementation of the project, (3) Post-test that is content coordinated with pre-test is distributed to the respondents, and (4)The pre-test and post-test scores are gathered and 
INTERNATIONAL JOURNAL OF ACADEMIC RESEARCH IN PROGRESSIVE EDUCATION AND DEVELOPMENT

Vol. 8, No. 4, 2019, E-ISSN: 2226-6348 @ 2019 HRMARS

compared to evaluate the changes that occur within the findings from pre and post-treatment using computerized statistical software 'IBM SPSS Statistics' version 22.

\section{Research Finding}

H01: There is no significant difference in mastery of applying skill through PBL during pre-test and post-test.

Table 3. Comparison between Pre-test and Post-test Grade/Marks of Applying Skill

\begin{tabular}{|c|c|c|c|c|}
\hline \multirow[b]{2}{*}{ Grade (Marks) } & \multicolumn{2}{|c|}{ Pre-test } & \multicolumn{2}{|c|}{ Post-test } \\
\hline & Frequenc & Percentage & Frequenc & Percentage \\
\hline$A+(90-100)$ & 0 & 0 & 3 & 7.5 \\
\hline$A(80-89)$ & 0 & 0 & 4 & 10 \\
\hline A- (70-79) & 0 & 0 & 5 & 12.5 \\
\hline$B+(65-69)$ & 10 & 25 & 6 & 15 \\
\hline B (60-64) & 4 & 10 & 10 & 25 \\
\hline$C+(55-59)$ & 6 & 15 & 7 & 17.5 \\
\hline C (50-54) & 5 & 12.5 & 3 & 7.5 \\
\hline D (45-49) & 10 & 25 & 2 & 5 \\
\hline$E(40-44)$ & 2 & 5 & 0 & 0 \\
\hline G (0-39) & 3 & 7.5 & 0 & 0 \\
\hline Total & 40 & 100 & 40 & 100 \\
\hline
\end{tabular}

Table 3 indicates the finding of grade difference that is acquired by the respondents during pre-test and post-test. The finding shows that the highest grade achieved in pre-test is $\mathrm{B}+$ that is represented by $25 \%$ of the research sample while the lowest grade achieved is $G$ that is represented by $7.5 \%$ of the research sample. The lowest grade implies that 3 students fail the pre-test. As for post-test, 3 students received A+ grade which represents $7.5 \%$ of the research sample and it is the highest grade achieved. Meanwhile, the lowest grade in post-test is acquired by 2 students with $D$ grade which is $5 \%$ of the research sample.

Next, mean value of applying skill performance through PBL in pre-test and post-test is gained through execution of paired t-test. Results from paired t-test for applying skill are displayed in Table 4. 
INTERNATIONAL JOURNAL OF ACADEMIC RESEARCH IN PROGRESSIVE EDUCATION AND DEVELOPMENT

Vol. 8, No. 4, 2019, E-ISSN: 2226-6348 @ 2019 HRMARS

Table 4. Results for t-test on Applying Skill Performance through PBL

\begin{tabular}{lllll}
\hline Sample & $\mathrm{M}$ & $\mathrm{SP}$ & $\mathrm{T}$ & $\mathrm{P}$ \\
\hline Pre-test & 154.43 & 10.19 & 12.90 & .000 \\
Post-test & $، 65.55$ & 11.14 & & \\
\hline
\end{tabular}

Table 4 signifies analysis of t-test from pre-test and post-test that is carried out on the experiment group. The result shows that there is a significant difference in terms of the mean value for the experiment group, $\mathrm{t}(39)=12.90, \mathrm{p}=.000$. Thus, $\mathrm{H} 01$ is rejected.

H02: There is no significant difference in mastery of analyzing skill through PBL during pre-test and post-test.

Table 5

Comparison between Pre-test and Post-test Grade/Marks of Analyzing Skill

\begin{tabular}{|c|c|c|c|c|}
\hline \multirow[b]{2}{*}{ Grade (Marks) } & \multicolumn{2}{|c|}{ Pre-test } & \multicolumn{2}{|c|}{ Post-test } \\
\hline & Frequenc & Percentage & Frequenc & Percentage \\
\hline$A+(90-100)$ & 0 & 0 & 9 & 22.5 \\
\hline A (80-89) & 0 & 0 & 3 & 7.5 \\
\hline A- (70-79) & 0 & 0 & 6 & 15 \\
\hline$B+(65-69)$ & 8 & 20 & 6 & 15 \\
\hline B (60-64) & 3 & 7.5 & 11 & 27.5 \\
\hline$C+(55-59)$ & 5 & 12.5 & 2 & 5 \\
\hline C (50-54) & 7 & 17.5 & 2 & 5 \\
\hline D (45-49) & 12 & 30 & 1 & 2.5 \\
\hline$E(40-44)$ & 1 & 2.5 & 0 & 0 \\
\hline G (0-39) & 4 & 10 & 0 & 0 \\
\hline Total & 40 & 100 & 40 & 100 \\
\hline
\end{tabular}

Comparison between pre-test and post-test grade/marks of the experiment group is shown through Table 5 . The highest grade attained by the students in pre-test is $B+(20 \%)$ while the lowest grade attained by the students in pre-test is $\mathrm{G}(10 \%)$. As for post-test, the highest grade attained by the students is $A+(22.5 \%)$ while the lowest grade attained by the students is $\mathrm{D}(2.5 \%)$. Based on the result, it is observed that the number of students that attained $\mathrm{G}$ grade decrease between pre-test and post-test from $4(10 \%)$ students to $0(0 \%)$. 
INTERNATIONAL JOURNAL OF ACADEMIC RESEARCH IN PROGRESSIVE EDUCATION AND DEVELOPMENT

Vol. 8, No. 4, 2019, E-ISSN: 2226-6348 @ 2019 HRMARS

Table 6. T-test on Analysing Skill Performance through PBL

\begin{tabular}{|c|c|c|c|c|c|}
\hline Sample & & & SP & $\mathrm{T}$ & $P$ \\
\hline Pre-test & ، 53.25 & 9.50 & -22.75 & .000 & \\
\hline Post-test & ، 71.75 & 13.40 & & & \\
\hline
\end{tabular}

Table 6 shows the findings from the t-test on analysing skill in pre-test and post-test. The finding shows that the mean value $(M=71.75)$ for post-test is higher compared to the mean value $(M=53.25)$ for pre-test. This finding denotes that there is a significant difference between the mean value of pre-test and post-test, $t(39)=-22.75, p=.000$. Therefore, $\mathrm{H} 02$ is rejected.

H03: There is no significant difference in mastery of evaluating skill through PBL during pre-test and post-test.

Table 7. Comparison between Pre-test and Post-test Grade/Marks of Evaluating Skill

\begin{tabular}{|c|c|c|c|c|}
\hline \multirow[b]{2}{*}{ Grade (Marks) } & \multicolumn{2}{|c|}{ Pre-test } & \multicolumn{2}{|c|}{ Post-test } \\
\hline & Frequenc & Percentage & Frequene & Percentage \\
\hline$A+(90-100)$ & 0 & 0 & 1 & 2.5 \\
\hline A (80-89) & 0 & 0 & 5 & 12.5 \\
\hline A- $(70-79)$ & 0 & 0 & 4 & 10 \\
\hline$B+(65-69)$ & 6 & 15 & 7 & 17.5 \\
\hline B (60-64) & 5 & 12.5 & 12 & 30 \\
\hline$C+(55-59)$ & 5 & 12.5 & 5 & 12.5 \\
\hline$C(50-54)$ & 3 & 7.5 & 4 & 10 \\
\hline D (45-49) & 11 & 27.5 & 2 & 5 \\
\hline E (40-44) & 5 & 12.5 & 0 & 0 \\
\hline G (0-39) & 5 & 12.5 & 0 & 0 \\
\hline Total & 40 & 100 & 40 & 100 \\
\hline
\end{tabular}

Comparison between pre-test and post-test grade/marks in evaluating skill is portrayed in Table 7. In pre-test the highest grade acquired by the students is $B+(15 \%)$ while the lowest grade acquired by the students is $\mathrm{G}(12.5 \%)$. Meanwhile, post-test shows that the highest grade acquired by the students is $A+(2.5 \%)$ while the lowest grade acquired by the students is $D(5 \%)$. According to the results, the number of students that acquire $\mathrm{G}$ grade decrease from 5 (12.5\%) students to 0 students as compared from pre-test and post-test.

Table 8. T-test for Evaluating Skill Performance through PBL

\begin{tabular}{llllll}
\hline Sample & $\mathrm{N}$ & $\mathrm{M}$ & $\mathrm{SP}$ & $\mathrm{T}$ & $\mathrm{P}$ \\
\hline Pre-test & 40 & 51.28 & 10.08 & -20.94 & .003 \\
Post-test & 40 & 64.42 & 10.20 & &
\end{tabular}


Vol. 8, No. 4, 2019, E-ISSN: 2226-6348 @ 2019 HRMARS

Table 8 signifies the result of t-test from pre-test and post-test for evaluating skill. The finding shows that the mean value $(M=51.28)$ for pre-test is lower compared to the mean value $(M=64.42)$ for post-test. As a result, there is a significant difference in terms of mean value between pre-test and post -test on the experiment group, $t(39)=-20.94, p=.003$. Hence, $\mathrm{HO3}$ is rejected.

H04: There is no significant difference in mastery of creating skill through PBL during pre-test and post-test.

Table 9. Comparison between Pre-test and Post-test Grade/Marks for Creating Skill

\begin{tabular}{|c|c|c|c|c|}
\hline \multirow[b]{2}{*}{ Grade (Marks) } & \multicolumn{2}{|c|}{ Pre-test } & \multicolumn{2}{|c|}{ Post-test } \\
\hline & Frequenc & Percentage & Frequenc & Percentage \\
\hline$A+(90-100)$ & 0 & 0 & 0 & 0 \\
\hline A (80-89) & 0 & 0 & 5 & 12.5 \\
\hline A- (70-79) & 0 & 0 & 4 & 10 \\
\hline$B+(65-69)$ & 4 & 10 & 2 & 5 \\
\hline B (60-64) & 3 & 7.5 & 13 & 32.5 \\
\hline$C+(55-59)$ & 6 & 15 & 8 & 20 \\
\hline$C(50-54)$ & 5 & 12.5 & 1 & 2.5 \\
\hline D (45-49) & 6 & 15 & 6 & 15 \\
\hline$E(40-44)$ & 9 & 22.5 & 1 & 2.5 \\
\hline G (0-39) & 7 & 17.5 & 0 & 0 \\
\hline Total & 40 & 100 & 40 & 100 \\
\hline
\end{tabular}

Comparison between Pre-test and Post-test grade/marks for creating skill is shown in Table 9. The highest grade obtained by the students in pre-test is $B+(10 \%)$ while the lowest grade obtained by the students in pre-test is $\mathrm{G}(17.5 \%)$. In the meantime, post-test displays a result of the highest grade obtained by the students is $A(12.5 \%)$ while the lowest grade obtained by the students is $E(2.5 \%)$. According to Table 9, there is a decrease in the number of students obtaining grade $\mathrm{G}$ from $7(17.5 \%)$ students to $0(0 \%)$ between pre-test and post-test.

Table 10. T-test on Creating Skill Performance through PBL

\begin{tabular}{lllll}
\hline Sample & $\mathrm{M}$ & $\mathrm{SP}$ & $\mathrm{T}$ & $\mathrm{P}$ \\
\hline Pre-test & 149.1 & 9.78 & -13.96 & .000 \\
Post-test & $، 62.63$ & 11.63 & & \\
\hline
\end{tabular}

Table 10 displays the result from t-test for creating skill in pre-test and post-test on the experiment group. The finding shows that the mean value $(M=62.63)$ for post-test is higher compared to mean value $(M=49.1)$ of pre-test. Consequently, it is observed that there is a 
significant difference between pre-test and post-test, $t(39)=-13.96, p=.000)$. Thus, H04 is rejected.

Overall, the researcher found that all hypotheses are rejected. This conclusion was made based on the research finding that there was significant difference between mean values in pre-test and post-test in mastery of HOTS that covers the applying, analysing, evaluating and creating skill. Therefore, analysis of data proofed that the scaffolding element in PBL contributes towards achievement in reinforcement of accounting students HOTS mastery specifically in "Cash Budget" topic.

\section{Discussion}

The application of PBL with scaffolding strategy was observed as able to assist 40 accounting students in reinforcing their mastery of HOTS for "Cash Budget" topic. The implementation of scaffolding element caused none of the research sample attained grade $G$ in the post-test. Hence, this signifies that the involvement of scaffolding element in various Teaching and Learning techniques must be taken into consideration. Overall, the students were able to improve their performance in the topic studied.

According to the first hypothesis (H01), there was a significant difference shown in the research finding for pre-test and post-test. The finding indicates that there is an increase in the accounting students' level of mastery of applying skill in "Cash Budget" topic. Next, the second hypothesis (H02) denoted that there was a significant difference in the analysis result from the pre-test and post-test. This shows that there is an increase in the accounting students' level of mastery of analysing skill in "Cash Budget" topic. The third hypothesis ( $\mathrm{H03}$ ) also displayed a result of there was a significant difference in the result analysis of pre-test and post-test. In line with that statement, there is an increase in the level of mastery of evaluating skill among the accounting student in "Cash Budget" topic.

The finding from the research hypotheses supports and is supported by a few past researches which proved scaffolding element in PBL are able to reinforce students mastery of HOTS in Teaching and Learning session in schools (See et al., 2015: Bell, 2010). Therefore, the research result explains and expose to the teachers on ways to assist weak students in studying which eventually give exposure towards a more effective learning strategy that can be implemented in Teaching and Learning session in schools.

\section{Conclusion}

Based on the findings and discussions, all hypothesis are rejected. This objection proved that there was a significant difference in mastery of applying, analyzing, evaluating, and creating skills through PBL during pre-test and post-test. Besides, from the findings and discussion above, it's has been proven that scaffolding is an important element in Teaching and Learning session and 
must be emphasized in order to create a successful Teaching and Learning session in schools. However, issues such as time constraint, lack of skilled workforce and sources (Salam et al., 2014) affect the desire to reinforce the students mastery of HOTS and implementation of various strategies in Teaching and Learning session (See et al., 2015). By focusing on good time management, finding opportunities for learning various teaching techniques and establishing relationships between educators in Malaysia and overseas to ensure that educators are able to create effective and effective teaching and learning sessions. Thus, the researcher supports statement by Yusof (2017) about providing various courses regarding reinforcement of HOTS among educators by implementing diverse skills in teaching and learning strategy. Therefore, further research regarding other teaching and learning strategy as suggested through Standard Achievement Documents (SAD) in accounting subject to observe the students' mastery of HOTS must be carried out in order to gain an overall result of the effectiveness of the various strategies applied in Teaching and Learning session in schools.

\section{Acknowledgement}

The researchers also like to acknowledge the University Putra Malaysia for the financial funding of this research through "Geran - Putra IPS" UPM (GP-IPS/2018/9608800), for Research University Grant (RUG).

\section{Corresponding Author}

Suhaida Kadir is associate professor at the Faculty of Educational Studies, Universiti Putra Malaysia, Selangor Darul Ehsan, Malaysia. Email: suhaida@upm.edu.my

\section{References}

Abosalem, Y. (2016). Assessment Techniques and Students' Higher-Order Thinking Skills. International Journal of Secondary Education, 4(1), 1-11.

Anderson, O. W. \& Krathwohl, D. R. (2001). Taxonomy for Learning, Teaching, and Assessing: A Revision of Bloom's Taxonomy of Educational Objectives. A Bridged Edition. New York: Addison Wesley Longman, Inc.

Curriculum Development Department. (2016). Buku Penerangan Kurikulum Standard Sekolah Menengah (KSSM). Putrajaya: Kementerian Pendidikan Malaysia.

Barak, M. \& Shachar, A. (2008). Project in Technology Education and Fostering Learning: The Potential and Its Realization. Journal Sciences Education Technology, 17: 285-296.

Bathuma, S. dan Kalaimakal, P. (2014). The Usage of Language Learning Strategies in Malaysian Private Secondary Schools. Advances in Language and Literary Studies Vol. 5, No.4.

Bowles, D., Radford, J. \& Bakopoulou, L. (2017). Scaffolding as a Key Role for Teaching Assistants: Perceptions of Their Pedagogical Strategies. British Journal of Educational Psychology, 2017.

Chen, L. Understanding critical thinking in Chinese sociocultural contexts: A case study in a Chinese college. Thinking Skills and Creativity, 2017, 24, 140-151. 
INTERNATIONAL JOURNAL OF ACADEMIC RESEARCH IN PROGRESSIVE EDUCATION AND DEVELOPMENT

Vol. 8, No. 4, 2019, E-ISSN: 2226-6348 @ 2019 HRMARS

Conklin, W. (2012a). Higher- Order thinking skills to develop 21st century learner. Huntington Beach, United States of America: Shell Education Publishing Inc.

Conklin, W. (2012b). Strategies for Developing Higher-order Thinking Skills. Huntington Beach, United States of America: Shell Education Publishing Inc.

Frank, M. \& Barzilai, A. (2004). Integrating Alternative Assessment in A Project-Based Learning Course for Pre-Service Science and Technology Teachers. Assessment \& Evaluation in Higher Education, 29(1), 41-61.

Guthrie, C. (2008). Towards Greater Learner Control: Web Supported Project-Based Learning. Journal of Information Systems, 21(1): 121-131.

Hassan, R. (2017). Gaya dan Strategi Pembelajaran Bahasa Melayu dalam Kalangan Pelajar Perancis. Journal of Language Studies, 17(1), 125-146.

Heong, Y. M., Othman, W. B., Yunos, J. B. M., Kiong, T. T., Hassan, R. B., \& Mohamad, M. M. B. (2011). The Level of Marzano Higher Order Thinking Skills among Technical Education Students. International Journal of Social Science and Humanity, 1(2), 121.

Kizkapan, O. \& Bektas, O. (2017). The Effect of Project Based Learning on Seventh Grade Students' Academic Achievement. International Journal of Instruction, Vol. 10, No.1.

Lin, S. F., \& Lin, H. (2016). Learning Nanotechnology with Texts and Comics: The Impacts on Students of Different Achievement Levels. International Journal of Science Education, 38(8), 1373-1391.

Ministry of Education (2013). Pelan Pembangunan Pendidikan Malaysia 2013-2025 (Pendidikan Prasekolah hingga Lepas Menengah). Putrajaya: KPM.

Ministry of Education (2015). Kemahiran Berfikir Aras Tinggi (KBAT) dan Perlaksanaan KBAT di Sekolah. Buletin Anjakan, 1-4. Retrieved from

http://www.padu.edu.my/files/Anjakan_Mac_2015.pdf

Ministry of Education (2017). Laporan Tahunan 2016 (Pelan Pembangunan Pendidikan Malaysia 2013-2025). Putrajaya: Kementerian Pendidikan Malaysia. Retrieved from http://www.moe.gov.my

Yusof, M. K. (2017). Laporan Tahunan 2016 (Pelan Pembangunan Pendidikan Malaysia 20132025). Putrajaya: Kementerian Pendidikan Malaysia. Retrieved from http://www.moe.gov.my

Arshad, M. A. Y. \& Yasin, M. R. (2015). Kemahiran Berfikir Aras Tinggi murid dalam Konteks Penyelesaian Masalah bagi Mata Pelajaran Sains. Asian Education Action Research Journal, 4, 81-96.

Nordin, A. B. (2013). Kurikulum ke Arah Penghasilan Kemahiran Berfikiran Kritis, Kreatif dan Inovatif. Jurnal Kurikulum \& Pengajaran Asia Pasifik, Bil 1, Isu 1.

Onosko, J. (1991). Barriers to the Promotion of Higher-Order Thinking in Social Studies. Journal of Curriculum Studies, 19(4), 341-366.

Othman, Y. \& Osman, S. (2014). Keupayaan Menguasai Kemahiran Menulis Melalui Pembelajaran Berasaskan Projek dalam Penulisan Berbentuk Risalah di Sekolah Rendah. Jurnal Pendidikan Bahasa Melayu, Vol. 4, Bil. 1, ms 19-29. 
Robinson, J. (2013). Project-Based Learning: Improving Student Engagement and Performance in the Laboratory. Analytical \& Bioanalytical Chemistry 405 (1): 7-13. Doi: 10.1007/s00216012-6473-x.

Saregar, A., Latifah, S., \& Sari, M. (2016). The effectiveness of model learning cups: impact on the higher order thinking skill students at madrasah aliyah mathla'ul anwar gisting lampung. Jurnal Ilmiah Pendidikan Fisika Al-BiRuNi, 5(2), 235-246.

See, Y. G., Rashid, M. A. \& Bakar, A. R., (2015). The Effect of Project Based Learning on Level of Content Knowledge of Pre-Vocational Subject. Mediterranean Journal of Social Sciences, Vol 6, No 6. S4.

Noah, S. M. (2002). Reka bentuk penyelidikan: Falsafah, teori dan praktis. Serdang: Penerbit Universiti Putra Malaysia.

Vygotsky, L. S. (1978). Mind in Society - The Development of Higher Psychological Processes. Cambridge: Harvard University Press.

Wijnen, M., Loyens, S. M. M., Smeets, G., Kroeze, M., \& Molen, V. D. H. (2017). Comparing Problem-Based Learning Students to Students in A Lecture-Based Curriculum: Learning Strategies and The Relation With Self-Study Time. European Journal of Psychology of Education, 32(3), 431-447.

Wilkin, C. L. (2017). Enhancing Critical Thinking: Accounting Students' Perceptions. Education + Training, 59(1), 15-30. https://doi.org/10.1108/ET-01-2015-0007.

Williams, B. R. (2003). Higher-Order thinking skills; Challenging all students to achieve. Corwin Press.

Wood, D., Bruner, J. S. \& Ross, G. (1976). The Role of Tutoring in Problem Solving. Journal of Child Psychology \& Psychiatry \& Allied Disciplines, 17(2): 89-100. Doi:10.1111/1469-7610. 